\title{
3. 職域における健康管理情報と個人情報保護法
}

\author{
安福 壃一 \\ 新日本製鐵㑣) 人事・労政部 安全健康グループ
}

はじめに

平成 17 年 4 月 1 日、個人情報保護法が施行されてから本学会のこのシンポジウム開催までに 1 年が経 過した。個人情報保護法は、労衝衛生に関する情報だけに適用されるものでなく、労衝衛生を担当する者 だけが本法への適用を迫られた訳ではない。健康管理を担当する者には、健康管理に係わる情報が「生存 する個人に関する情報であって、氏名、生年月日などにより、個人が誰であるかを識別することができる 情報」であるだけに、法の成立以降、今日まで様々な場面で情報交換や議論の場が設けられてきた。

しかし、どこの場の議論であっても「これさえ遵守していれば適法である」、あるいは「法遵守のため にはこれをきちんとすべきである」とうい結論めいた回答を頂いたことはない。いまだに試行錯誤が続い ているといってもよいであろう。むしろ最近ではこの法律の適用を受けて罰せられたというより、行き過 ぎた法対応を少し修正しているというお話を聞くことすらある。

ここでは、1企業の中で衛生管理者としてまた健康管理全般を企画している立場から、この 1 年間この 法律への対応に何をすれば良いのか考えながら、進めてきたことを紹介して話題の提供としたい。

1. 企業内で健康管理情報とそれを取り扱う者

まず、企業の中で健康管理情報をどんな機会に、どんな人たちが入手できるのか、想定できることを整 理してみる。

1）健康管理に関する情報

(1) 労㗢安全衛生法に基づくもの

・法で定める一般健康診断、特殊健康診断、臨時の健康診断の結果と産業医 (医師) 等から聴取した意 見と就業上の措置等

・法に基づいて行った保健指導の結果等

・トータル・ヘルス・プロモーションプラン $(\mathrm{THP})$ 等を通じて得られる健康測定結果

・その他、企業内の健康管理スタッフの持つ情報

(2) 労働者災害補償保険法に基づいて労働者から提出される健康診断情報等

(3) 使用者と労働者の話し合いによって法定項目以外に加えられた健康診断情報

(4) 労働者から休業等の届出理由や就業配慮理由として提出された外部の医療機関受診の健康管理情報 (診断書)

(5) メンタルヘルス、HIV 感染のような特に機微な情報

（6) 健康保険組合が行う保健事業 (福利厚生施策) や療養給付の情報 (会社と健保組合の共同事業もあり)

2）健康管理情報を取り扱う者

健康管理情報を取り扱う者は、企業の規模や組織のあり方によってかなり異なるが、一般的には次の人 たちであろう。 
(1) 産業医

(2) 衛生管理者

(3) 企業内の産業保健師、看護師、カウンセラー、栄養士等

(4) 健康管理部門の事務スタッフ

(5) 健康保険組合のスタッフ

(6) 人事担当スタッフ

(7) 健康管理システムに関わるシステムエンジニア

2. 健康管理情報の利用、活用について（保護をどうするか）

健康管理情報は、個人情報の中でも特別に扱われなければならない情報であることは間違いない。特に わが国では、一般健康診断の実施を含めて事業者にその実施義務を課していることから、労働者の個人情 報でありながら事業者が同じ情報を持つという特殊性がある。健康診断情報の入手については、健康診断 の内容と本人にフィードバックする内容をきちんと合意することが何よりも大切である。

また、事業者が利用する範囲を必要最小限に留めるなどの配慮は当然必要とされ、適正に運用されてい ることを労使の間で必要に応じて説明する仕組みを構えておくことが重要である。

そこで、健康管理を行う上で事業者が注意を払うべきことを列挙してみる。

1）利用の目的を開示、明示する

2）利用の目的に必要な情報以外の情報は極力持なない

3）利用の目的以外に利用や提供はしない

4）利用の目的に使用する情報は正確性を担保する努力をする

5）保持する情報の安全を確保する

6）情報を取り扱う者の取り扱う情報の範囲と守秘義務を徹底する

7）．本人への開示 (通知) と説明（ルール作りへの参加）

健康診断を健康であることの確認に捉えれば、「異常がない」、「保健指導の必要がない」場合、労働者 の側に自らの健康診断結果に関心を持たない者が時々見受けられるが、産業医をはじめとする健康管理 スタッフは地道にこの人たちへの説明も忘れてはならない。

終うりに

健康管理情報は、個人情報として極めてその保護が大切にされなければならない情報である。一方で は、様々な機会を通じて入手され、多くの関係者が関与している情報でもある。最も重要なことは、個人 の健康管理に最優先して活用できるように十分な配虑をすべきことである。法で決められて事業主に義 務づけられた健康診断といえども、各事業所の健康管理責任者は、「健康管理は個々人から預かったもの」 として労使の間で最大限生かされるような仕組みを構築する努力をすべきである。 